\title{
BENTUK, FUNGSI, DAN MAKNA LELAKAQ SASAK SEBAGAI MEDIA KAMPANYE CALON WALIKOTA MATARAM
}

\author{
Usman Jayadi \\ Mahasiswa Pascasarjana Program Studi Pendidikan Bahasa Indonesia, \\ Universitas Mataram, NTB, Indonesia \\ ujayadi@gmail.com
}

\begin{abstract}
Lelakaq Sasak is one of the important culture use to give suggestion to people in Lombok island. Nowadays Lelakaq Sasak uses as campaign tool to attract constituent like in head village election, legislative, governor and regency election. The goal of this research is to know the segment of how Lelakaq Sasak types, function and Lelakaq Sasak mean in Mataram regency campaign. The method of collecting data in this research are observation, quotation, document and in analysis data use structural analysis and Semiotic for type analysis. Analysis function use approach hermeneutic. The research result that we know the type of Lelakaq Sasak in Mataram regency campaign. The purpose of Lelakaq Sasak about describes event and feeling.
\end{abstract}

Keywords: type, function, and meaning of Lelakaq Sasak in Mataram candidate regency election campaign.

\begin{abstract}
ABSTRAK
Lelakaq merupakan salah satu budaya penting yang digunakan dalam menyampaikan pesan-pesan mulia kepada masyarakat di wilayah Pulau Lombok. Akhir-akhir ini lelakaq digunakan sebagai media kampanye untuk menarik simpati pemilih, baik dalam pemilihan kepala desa, anggota legislatif, gubernur/wakil gubernur, dan bupati/walikota. Penelitian ini bertujuan menyermati sigmen bagaimana bentuk, fungsi, dan makna lelakaq pada saat kampanye Walikota Mataram. Metode yang digunakan dalam mengumpulkan data adalah observasi, pencatatan, dokumentasi, sedangkan analisis data menggunakan analisis struktural dan semiotik untuk analisis bentuk. Analisis fungsi menggunakan pendekatan fungsi dan analisis makna dengan pendekatan hermeneutik. Hasil penelitian yang diperoleh yaitu bentuk lelakaq pada saat berlangsungnya kampanye Walikota Mataram. Makna lelakaq berisi tentang pelukisan perasaan dan peristiwa.
\end{abstract}

Kata kunci: bentuk, fungsi, dan makna lelakaq, kampanye calon walikota mataram

\section{PENDAHULUAN}

Dinyatakan dalam penjelasan Undang-Undang Dasar 1945 Bab XIII pasal 32 bahwa kebudayaan bangsa adalah kebudayaan yang timbul sebagai hasil budidaya masyarakat Indonesia seluruhnya. Kebudayaan yang lama dan asli 
terdapat sebagai puncak-puncak kebudayaan di Indonesia, terhitung sebagai kebudayaan asli bangsa. Usaha kebudayaan harus menuju kepada kebudayaan adab, budaya, dan persatuan dengan tidak menolak kebudayaan atau bahan-bahan baru yang dapat memperkembangkan dan memperkaya budaya bangsa sendiri, serta mempertinggi derajat kemanusiaan bangsa Indonesia.

Dalam rangka mencari identitas bangsa maupun suku-suku bangsa yang ada di Indonesia, ahir-ahir ini, di pusat atau di daerah telah timbul kegairahan untuk mengumpulkan bentuk-bentuk folklor dari semua suku bangsa yang ada di Indonesia (Danandjaja, 1986 : 153) Hal itu dapat dibuktikan dengan begitu banyaknya penemuan para ahli yang dipublikasikan dalam bentuk buku dan artikel.

Folklor merupakan salah satu aspek kebudayaan yang perlu dikembangkan dan dipelihara agar sastra daerah dapat bertahan, disamping itu agar nilai-nilai yang terkandung di dalamnya dapat dijadikan referensi oleh masyarakat pemiliknya dan masyarakat Indonesia pada umumnya. Salah satu cara untuk mencapai hal tersebut adalah melalui penelitian.

Salah satu jenis folklor yang masih hidup di Pulau Lombok adalah Lelakaq. Lelakaq adalah ungkapan tradisional yang menyerupai pantun, terdiri dari empat baris berupa dua bari sampiran dan dua baris isi yang sering dibawakan pada upacara tradisional Sasak. Sebagai salah satu bentuk budaya, lelakaq bertujuan mengkomunikasikan pikiran masyarakat yang tumbuh dan berkembang dari waktu ke waktu. Lelakaq yang hidup dan berkembang di tengah-tengah masyarakat merupakan salah satu media yang efektif untuk menyebarkan nilai-nilai kebaikan kepada masyarakat Sasak (Yudi Handoko Himawan, 2012).

Penelitian ini menggunakan pendekatan etnolinguistik karena disiplin ilmu ini mempunyai pemahaman bahwa bahasa itu sangat terkait dengan budaya. Secara garis besar prosedur penelitian ini meliputi enam tahap kegiatan. Keenam kegiatan tersebut adalah mengumpulkan data, membuat catatan lapangan, menyeleksi data, menterjemahkan dan menafsirkan data ke dalam bahasa Indonesia, menganalisis data berdasarkan fokus penelitian, dan menulis laporan. Dalam tahap pengumpulan data, peneliti menggunakan metode simak dan wawancara. Metode simak dilakukan terhadap sumber lisan dan tertulis, sumber lisan berupa rekaman lagu-lagu Sasak dalam kegiatan kampanye para calon bupati/walikota yang banyak menggunakan lelakaq dalam 
liriknya, sementara sumber tertulis berupa teks atau lirik lagu kampanye para calon bupati/walikota. Peneliti sebagai penutur asli bahasa Sasak juga memanfaatkan metode introspektif, yaitu dengan mensinergikan pemahamannya tentang lelakaq. Pada akhirnya, penelitian ini menghasilkan pemaparan mengenai karakteristik lelakaq sebagai wacana, serta memaparkan sistem kognisi masyarakat Sasak yang tercermin dalam lelakaq. Dalam menciptakan lelakaq, masyarakat Sasak dipengaruhi oleh pengalaman, yakni interaksinya terhadap dunia sekitar. Terdapat banyak referensi lelakaq yang berhubungan dengan kehidupan sekitar, baik terkait interaksi mereka dengan sesama manusia, interaksi dengan Tuhan, dan interaksi dengan alam lingkungan sekitar. Melalui lelakaq, masyarakat Sasak menyampaikan berbagai macam persoalan dan pandangan hidup mereka. Lelakaq dapat dijadikan sebagai pengendali dan penilai terhadap tingkah laku masyarakat Sasak, yang berujung pada terciptanya keserasian hidup, baik dengan Tuhan, sesama manusia, dan lingkungan sekitar.

Berdasarkan latar belakang di atas dapat dirumuskan permasalahan sebagai berikut: Bagaimanakah bentuk, fungsi, dan makna Lelakaq pada masyarakat Sasak sebagai media kampanye calon Walikota Mataram Tahun 2015?

\section{TEORI DAN METODOLOGI}

Metode kajian sastra lisan, sedikit berbeda dengan sastra lain. Kajian sastra lisan membutuhkan metode khas. Kajian sastra lisan seyogyanya meliputi: (1) pengumpulan (collection), klasifikasi (classifition), dan analisis (analysis) (Dundes, 1968: 121) koleksi sastra lisan, dimaksudkan untuk pelestarian. Koleksi data dapat meliputi aspek seks umur, profesi pemilik, sehingga diketahui peranannya. Yang paling penting direnungkan adalah pernyataan tokoh tersebut. Penulis juga meng'iya'kan gagasan ini. Sebab dengan koleksi, pemahaman, dan analisis satra lisan akan diketahui pula tradisi pemiliknya. Maka pengkajian sastra lisan, perlu sampai pada tingkat peranan (rules).

Secara rinci pengkajian sastra lisan yang berusaha menemukan orisinalitas dan fungsi, dapat dikelompokkan dalam beberapa ranah: (1) historical orgins, yaitu studi kearah sejarah kapan dan di mana sastra lisan itu ada, (2) psychological origins, artinya studi kearah mengapa sastra lisan ada, sifat-sifat apa yang melekat 
di dalamnya, dorongan kejiwaan apa yang melekat di dalamnya. Dua sifat penting sastra lisan yang perlu dicermati adalah multiple extence dan irracionality. Multiple extence berkaitan dengan aspek: (a) monogenesis (one birth), diffusion, dan (b) poliginesis (many birth). Monogenesis adalah sifat sastra lisan yang original kemudian disebarkan. Poligenesis, adalah temuan sebaliknya yaitu sastra lisan yang sama diberapa waktu dan wilayah.

Ikhwal irasionalitas, berkaitan dengan unsur magis dalam sastra lisan. Unsur ini dapat dijelaskan melalui pendekatan simbolik. Atas dasar hal tersebut berarti kajian sastra lisan boleh juga dicocokkan dengan sumber tulis. Kajian dapat menelusuri data lapangan (data primer) dan skunder (yang tertulis atau dokumen lain). Metode kajian tergantung wawasan yang hendak diraih. Dalam kaitan ini Abrams (1981: 3-29) menawarkan empat ranah kajian yatu : (a) pendekatan yang memerhatikan karya itu sebagai objek yang dibina melalui teknik-teknik tertentu atau pendekatan objektif. (b) pendekatan yang memerhatikan karya sebagai ungkapan emosi atau misi pribadi si pengarang, atau pendekatan ekspresif (c) pendekatan yang memerhatikan hubungan antara dunia dengan karya sastra lain dengan realitas di dalam semesta di luar karya.

Populasi adalah semua individu yang menjadi sumber pengambilan sampel (Komarudin, 1987: 53). Pendapat lain disebutkan bahwa "Populasi adalah keseluruhan subjek penelitian. Apabila seseorang ingin meneliti semua elemen yang ada dalam wilayah penelitian, maka penelitianya merupakan penelitian populasi" (Suharsimi Arikunto, 2002: 108). Populasi adalah keseluruhan sabjek yang dijadikan sasaran penelitian, populasi yang ada di Kota Mataram yang terkait dengan lelakaq adalah semua orang yang memiliki dan mengerti tentang lelakaq tersebut.

Sampel adalah sebagian atau wakil dari populasi (Suharsimi Arikunto, 1998: 140). Pendapat lain mengatakan bahwa sampel adalah sebagian kecil dari populasi yang digunakan dalam penelitian (Wirasapta K, 1995:48). Mengingat jumlah populasinya besar maka peneliti mengambil $20 \%$ dari jumlah populasi yang ada. Hal ini sejalan dengan pendapat yang menyatakan bahwa "Untuk sekedar ancar-ancar maka apabila subjeknya besar maka dapat diambil antara $10-15 \%$ atau $20-25 \%$ atau lebih tergantung dari setidak-tidaknya kemampuan peneliti dilihat dari segi waktu, tenaga dan dana (Suharsimi A, 1997: 112). 
Penelitian di lakukan di Kota Mataram, ibukota Provinsi Nusa Tenggara Barat yang memiliki banyak informan seperti tokoh masyarakat, tokoh adat dan ahli lelakaq dengan batasan usia minimal 40 tahun; serta masyarakatnya sebagian besar mengerti lelakaq untuk diterapkan dalam kehidupan sehari-harinya. Dari beberapa tokoh masyarakat dan ahli lelakaq yang dapat dijadikan sebagai informan adalah sebagian dari populasi yang ada. Kemudian yang dapat dijadikan sampel penelitian adalah 4 orang sebagai informan, Adapun kriteria informan sebagai berikut: (1) Informan berusia minimal 40 tahun; (2) Informan harus mengerti dan memahami tentang lelakaq. (3) Informan adalah seorang tokoh masyarakat yang mengetahui seluk-beluk lelakaq, yang berkembang di dalam masyarakat lokasi penelitian. (4) Informan seorang tokoh adat yang selalu menggunakan lelakaq, terutama dalam setiap acara. (5) Informan seorang ahli lelakaq yang mengetahui sejarah, ruang lingkup, terutama mengenai bentuk, fungsi lelakaq, khususnya lelakaq sebagai media kampanye.

Metode observasi adalah pengamatan dan pencatatan langsung secara sistematis dalam meningkatkan gejala atau fenomena yang diselidiki (Sutrisno Hadi, 1982: 136 ). Pendapat lain mengatakan observasi adalah suatu penyelidikan yang dilakukan secara sistematis dan sengaja diadakan dengan menggunakan alat indera (terutama mata dalam meningkatkan kejadian-kejadian yang langsung ditangkap pada kejadian itu terjadi ( Bimo Walgito, 1993: 54 ).

Obsevasi dilakukan untuk melengkapi dan memperkuat data-data yang diperoleh dari wawancara. Dimana observasi ini dilakukan secara terus menerus selama penelitian berlangsung. Yang diobservasi dalam penelitian ini adalah bagaimana eksistensi lelakaq dalam Kampanye calon Walikota Mataram yang disebarkan oleh tim kampanye calon melalui $\mathrm{CD}$, observasi juga digunakan untuk mengetahui bagaimana bentuk, fungsi, dan makna pada lelakaq sebagai media kampanye calon Walikota Mataram.

Wawancara adalah sebuah dialog yang dilakukan oleh seorang pewawancara untuk memperoleh informasi dari informan (Arikunto, 2006: 155). Metode wawancara yang digunakan peneliti adalah wawancara bebas terpimpin. Wawancara bebas terpimpin adalah tanya jawab secara lisan antara 
peneliti dengan responden, dengan mengajukan pertanyaan-pertanyaan secara bebas dan terarah.

Wawancara dilakukan pada tokoh masyarakat, tokoh adat, dan ahli lelakaq yang ada di Kota Mataram. Materi yang menjadi bahan wawancara adalah secara garis besar mencangkup bentuk, fungsi dan makna lelakaq kampanye calon Walikota Mataram dengan tujuan untuk memperoleh data secara lengkap, dan tidak ada pokok yang tertinggal. Wawancara dilakukan oleh dua orang yaitu pewawancara dan narasumber yang akan menjadi informan tempat pemperoleh data yang dibutuhkan.

Metode pencatatan ini sangat perlu, karena objek yang diteliti adalah hal yang tersembunyi dan penuh dengan syarat-syarat (tidak semua orang mengetahuinya), baik dalam proses penerimaan lelakaq-lakaqnya. Berhubungan dengan metode pencatatan ini, peneliti akan mencatat hal-hal yang perlu dan mungkin sulit untuk tidak dicatat (menggunakan cara lain) seperti syarat, kode atau sandi dalam pemakaian lelakaq pada informan atau narasumber yang berkompeten dibidangnya. Pencatatan dilakukan berkisar pada bentuk, fungsi, dan makna lelakaq bau nyale dan dilakukan pada saat wawancara berlangsung. Dengan tujuan untuk mengingat data yang diperoleh.

Metode dokumentasi yaitu sebuah metode yang apabila dalam pengumpulan data dirasakan sulit atau terlalu banyak untuk dicatat maka penulis akan menggunakan alat rekam (recorder/sejenisnya) untuk mendapatkan data yang berkaitan dengan ritual lelakaq kampanye calon Walikota Mataram. Teknik ini dilakukan dengan membaca literatur yang berkaitan dengan permasalahan dalam penelitian dan kumpulan jenis-jenis lelakaq yang telah didokumentasikan yang akan dianalisis.

Menurut Ahli Psikologi Sosial Mead (Duncan, 1962: 82) dalam bukunya Kutha Ratna yang dikatakan bahwa yang dimaksud dengan pengalaman estetis adalah kemampuan untuk mengungkapkan keindahan. Dalam ilmu sosial dan ilmu kealaman pada umumnya semua data di atas menjadi satu dengan data analisis, kemampuan untuk menguraikan objek sesuai dengan kaidah-kaidah, metode dan teori pengetahuan tertentu.

Langkah-langkah yang dilakukan dalam menganalisis sastra dalam bukunya Kutha Ratna (2007: 401), Schleiermacher (Palmer, 1982: 77-78) mengajukan tiga tahap proses pemahaman, yaitu: a) pemahaman historis, pemahaman isi karya, b) pemahaman gramatikal, pemahaman yang berkaitan dengan karya sastra, dan c) pemahaman jiwa 
pengarang dan semangat zamannya. Ketiga proses pemahaman tersebutdisejajarkan dengan tiga tingkat penjelasan, yaiti : a) penjelasan huruf yanng menjelaskan bahan baku sebuah teks (lelakaq), b) penjelasan makna, dalam hubungan ini disebut bentuk teks, dan c) penjelasan latar belakang pikiran dan kejiwaan teks (lelakaq).

Dalam karya seni, khususnya karya sastra, hermeneutika dianggap sebagai metode, sejajar bahkan sinonim dengan interpretasi, pemahaman, verstehen, dan deskriptif analisis. Dengan cara kerja yang hampir sama, dalam ilmu sosial disebut dengan metode kualitatif. Metode apapun bentuknya jelas memerlukan teori. Teori disesuaikan dengan sifat objek yang akan dianalisis, baik TeoriStrukturalisme maupun pstrukturalisme dengan masing- masing variannya. Teori dengan metode tidak perlu di aplikasikan secara persis sama sebagaimana diisyaratkan oleh para penemunya. teori dan metode dapat dimodifikasi sesuai dengan objeknya (Kutha Ratna, 2007 : 41)

Berdasarkan pendapat tersebut, dapat disimpulkan bahwa metode deskriptif kualitatif adalah cara penelitian yang lebih cenderung memaparkan apa adanya yang ditemui di lapangan tanpa menganalisis lebih ke dalam. Jadi metode deskriptif kualitatif ini digunakan untuk menarik kesimpulan hasil penelitian semua data yang telah digunakan dan dianalisis.

Hal ini dikarenakan terbatasnya waktu dan anggaran penelitian, sehingga metode deskriptif kualitatif dapat dipilih oleh peneliti. Selain dari persoalan waktu dan dana, penelitipun terganjal oleh kemampuan yang lebih rendah baik dari aspek pengetahuan yang menyangkut teori-teori dan sedikitnya pengalaman dalam masalah penelitian.

Dalam rangka penyusunan karya tulis ini, peneliti menggunakan metode deskriptif kualitatif, dengan langkah kerja yang digunakan adalah: (a) Mengumpulkan hasil penelitian yaitulelakaq kampanye Calon Walikota Mataram dari informan; (b) Menyelesaikan dan mengklasifikasikan data dari hasil penelitian; (c) Menguraikan dan menyimpulkan hal yang membangun suatu lelakaq dengan menggunakan teori struktural serta menggunakan bentuk, fungsi, dan makna yang terkandung dalam lelakaq di Kota Mataram; (d) Membuat kesimpulan akhir unsur yang terkandung dalam lelakaq. 


\section{TEMUAN DAN PEMBAHASAN}

Secara kontektual berdasarkan nilai estetik dan proses penciptaan lelakaq Kampanye Calon Walikota Mataram berupa tema, gaya bahasa, bunyi dan diksi (pemilihan kata). Lelakaq yang biasa digunakan oleh masyarakat sangat banyak, konteks lelakaq yang digunakan tergantung pada situasi penggunaannya, misalnya lelakaq pada saat kampanye, pada saat kampanye beraneka ragam lelakaq yang digunakan antara lain: lelakaq nasihat, agama, dan lain lain.

Berikut disajikan data lelakaq yang digunakan salah satu pasangan calon, yaitu Ahyar Abduh (Calon Walikota) dan Mohan Roliskana (Calon Wakil Walikota) atau yang disingkat pasangan AMAN (Ahyar-Mohan):

1) Lampaq menah lalo ngerakat = berangkat pagi mencari ikan

Galang Bulan leq Ampenan = tidak ada cahaya bulan di Ampenan

Iye Tetunah siq Masyarakat = dia disayang semua masyarakat

Ahyar-Mohan saq Tedemenan = Ahyar Mohan yang disenangi

2) Mun tedemen pade bedEngah = kalau suka bermain dengan anak kecil

Kapek paoq siq tetolang = lempar mangga dengan tulang

Teberiuk pade tunah = bersama kita sayang

Endeqte sanggup tebilin telang $=$ tidak sanggup ditinggal pergi

3) Beli nanas leq peken Cakre = beli nanas di Pasar Cakra

Beli Jaje leq Inaq Aminah = beli jajan di Inaq Aminah

Sengaq beleq gati jase = karena jasanya sangat besar

Iye doang saq tetunah = mereka saja yang disayang

Berdasakan teori fungsional, fungsi lelakaq dapat ditentukan bahwa setiap hasil kreasi budaya memiliki fungsi yang disesuaikan dengan kebiasaan dan aturan hidup masyarakat kolektifnya. Begitu juga halnya dengan lelakaq kampanye ini terbentuk dengan satu tujuan yang memiliki pranan penting dalam masyarakat khususnya di daerah penelitian. Lelakaq kampanye ini memiliki beberapa fungsi penting yang digambarkan dalam lelakaq yang disampaikan dalam bentuk lagu: Lelakaq nomor 1) berfungsi memberitahukan kepada semua orang atau masyarakat kalau pasangan calon yang dimaksud (Ahyar-Mohan) sangat disayang warga Masyarakat; Lelakaq nomor 2) berfungsi mengajak masyarakat memilih pasangan calon Walikota Mataram yakni 
Ahyar-Mohan; Dan Lelakaq nomor 3) berfungsi mendeskripsikan jasa-jasa pasangan Calon Walikota Mataram selama menjabat (incumbent).

Dari segi makna yang terkandung, Makna lelakaq nomor 1) mengungkapkan wilayah Ampenan yang merupakan salah satu wilayah di Kota Mataram sangat menyayangi pasangan Ahyar-Mohan; makna lelakaq nomor 2) yaitu pengungkapan secara tidak langsung kepada masyarakat agar memilih pasangan Ahyar-Mohan; Makna lelakaq nomor 3) yaitu pengungkapan kepada masyarakat agar merenungkan semua jasa-jasa pasangan calon incumbent (AhyarMohan).

Gaya basaha yang dipakai pada Lelakaq kampanye ini yaitu: Pada (lelakaq 1) menggunakan bahasa hiperbola terdapat pada (baris 2) yaitu mengungkapkan suatu peristiwa atau kejadian dengan gaya yang berlebih-lebihan yaitu: "Galang bulan leq Ampenan" yaitu tidak ada cahaya bulan di Ampenan, padahal sebenarnya tidak demikian, "Araq bulan leq Ampenan” yaitu pasti ada bulan di wilayah Ampenan tersebut.

Sedangkan lelakaq kedua pada baris ke-2 mengungkapkan suatu peristiwa yang sulit dicerna akal manusia, hal yang sebenarnya melempar mangga dengan kayu atau mengambilnya langsung dengan jala.

Rima tengah merupakan persamaan bunyi di tengah baris lelakaq seperti pada lelakaq. Pemilihan kata atau frase dalam lelakaq, disamping bermakna denotasi juga bermakna konotasi dalam mendukung situasi dan nilai rasa yang akan dikemukakan, misalnya lelakaq nomor tiga baris 4 yaitu kata "iye doang saq tetunah" berdenotasi semacam hanya pasangan ini saja yang disayang, sedangkan anak istri dan keluarga tidak disayang.

Metrum adalah irama yang tepat, artinya pergantiannya sudah tetap menurut pola tertentu. Hal ini disebabkan oleh jumlah suku katanya yang tepat sehingga alur suaranya yang menarik dan menurun adalah tetap. Dalam lelakaq kampanye ini terdapat semua lelakaq mengandung irama metrum.

Metrum Pada lelakaq di atas disengaja dibuat untuk mendapatkan persamaan bunyi dan irama yang menghasilkan keselarasan dengan kata. Rima merupakan pola estitika yang didasarkan pada pengurangan suara yang diusahakan yang dialami dengan kesadaran. 
Secara semiotik, yang mempelajari tentang sistem-sistem, aturan-aturan dan konvensi-konvensi yang memungkinkan bahasa sebagai tanda yang mempunyai arti. Pilihan kata-katanya dalamlelakaq kampanye sebagai lelakaq menarik minat masyarakat agar memilih pasangan calon dalam rangka kampanye Calon Walikota Mataram.

Berdasarkan pertimbangan dari semua analisa dalam penelitian ini, dapat diperoleh pembuktian bahwa pasangan Calon Walikota Mataram (Ahyar-Mohan) jauh lebih unggul dibandingkan satu pasangan lainnya yaitu, 77,25\% dan pesaingnya (Salman-Jana Hamdiana) 22,75\%. Ini menunjukkan bahwa lelakaq sasak yang digunakan oleh pasangan calon Walikota Mataram (Ahyar-Mohan) pada saat kampanye yang dituangkan melalui lagu-lagu dalam $\mathrm{CD}$, kemudian disebarkan ke masyarakat sangat produktif dan dapat ditiru oleh pasangan calon lainnya yang akan berkompetisi pada Pilkada 2017 atau 2018.

\section{SIMPULAN}

Berdasarkan permasalahan yang diajukan dalam penelitian ini dapat disimpulkan bahwa lelakaq sebagai budaya masyarakat di Pulau Lombok yang dikemas melalui lagu-lagu dapat dijadikan sebagai media kampanye politik dengan memerhatikan bentuk, fungsi, dan makna lelakaq yang digunakan oleh para calon yang berkompetisi, baik calon anggota legislatif, gubernur, bupati/walikota, dan lainnya. Penelitian ini sangat terbatas, diharapkan ada penelitian lain yang lebih baik dan dapat dijadikan panduan dalam membudayakan khasanah daerah yang tidak hanya dibidang pendidikan, tapi dibidang yang lainnya, seperti bidang politik dan ekonomi atau lainnya.

\section{UCAPAN TERIMA KASIH (ACKNOWLEDGEMENT)}

Terima kasih kepada Calon Walikota dan Calon Walikota Mataram terpilih yang telah mengangkat budaya daerah sebagai media kampanye, dan membuktikan bahwa budaya daerah sangat relevan untuk menarik minat masyarakat dalam kancah perpolitikan. Kepada para pembaca dan peneliti, semoga penelitian ini menjadi titik awal dalam mengangkat budaya-budaya daerah di Indonesia. 


\section{DAFTAR PUSTAKA}

Ancok, D. (1999). Validitas dan reliabilitas instrumen penelitian. dalam: Singarimbun M dan Efendi (Eds). Metode penelitian survey. Jakarta: LP3ES

Arikunto, S. (2002). Prosedur penelitian suatu pendekatan praktek. Jakarta: Rineka Cipta.

Endraswara. (2006). Metode, teori, teknik, penelitian kebudayaan: ideologi, epistemologi dan aplikasi. Yogyakarta. Pustaka Widyatama.

Lagu Ahyar-Mohan dapat diakses melalui https://www.youtube.com/watch?v=8YWiO$\underline{J x Z Q k}$

Lelakaq dalam budaya Sasak (analisis etnolinguistik)/Yudi Handoko Himawan S2.LING diakses melalui http://digilib.fib.ugm.ac.id/files/

Moleong, Lexy J. (2004). Metodologi penelitian kualitatif. Bandung. PT. Remaja Rosdakarya.

Santana K., Septiawan. (2010). Menulis ilmiah metodologi penelitian kualitatif. Jakarta: Yayasan Pustaka Obor Indonesia.

Sujarwa. (1998). Manusia dan fenomena budaya. Yogyakarta. Pustaka Belajar.

Surakhmad, Winarno. (1990). Pengantar penelitian ilmiah dasar, metode dan teknik. Bandung. Tarsito.

Takdir Alisjahbana, Sutan. (2011). Seni dan sastra di tengah-tengah pergolakan masyarakat dan kebudayaan. Jakarta: Penerbit Dian Rakyat.

Tim Penyusun Kamus Pusat Pembinaan dan Pengembangan Bahasa Depdikbud RI. (2008). Kamus besar bahasa Indonesia. Jakarta. Balai Pustaka.

Wellek, Rene dan Austin Warren. (1990). Teori kesusastraan. Jakarta: Gramedia.

Yule, George. (2015). Kajian bahasa edisi kelima. Yogyakarta: Pustaka Pelajar. 